\title{
Phasing and amplitude of sea-level and climate change during the penultimate interglacial
}

\author{
Andrea Dutton ${ }^{1 \star}$, Edouard Bard ${ }^{2}$, Fabrizio Antonioli ${ }^{3}$, Tezer M. Esat ${ }^{1 \dagger}$, Kurt Lambeck ${ }^{1}$ \\ and Malcolm T. McCulloch ${ }^{1}$
}

Earth's climate has oscillated between short-lived interglacial and extended glacial periods for the past million years. Before the last interglacial, absolutely dated markers of sea level become increasingly rare; hence, our knowledge of sea-level change driven by the waxing and waning of continental ice sheets before that time is largely based on proxy records from deep-sea cores $^{1-3}$ that lack direct age control. Here we present precise $\mathrm{U}$-Th ages for a remarkable collection of submerged speleothems ${ }^{4,5}$ from Italy, which record three sealevel highstands during the penultimate interglacial period, Marine Isotope Stage 7, from 245,000 to 190,000 years ago. We find that sea level rose above $-18 \mathrm{~m}$ (relative to modern sea level) several thousand years before maximum Northern Hemisphere insolation during the first and third highstands. In contrast, the second highstand, Marine Isotope Stage 7.3, is essentially synchronous with the insolation maximum, and sea level during this highstand only peaked at about $-18 \mathrm{~m}$, even though the concurrent insolation forcing was the strongest of the three highstands. We attribute the different phasing and amplitude of the Marine Isotope Stage 7.3 highstand to the extensive continental glaciation that preceded it. This finding highlights the significance of cryosphere response time to the climate system.

Reconstructions of previous interglacial periods can help elucidate the phasing and causal mechanisms linking temperature, sea level and greenhouse-gas concentrations that are critical to our understanding of climate dynamics during the present interglacial and into the future. Although the penultimate interglacial offers an important test for theories about the timing, duration, magnitude and driving mechanisms of sea-level highstands that have evolved out of studies of the last interglacial and the Holocene, fewer data are available for this period of time. Hence, the additional data presented herein provide an important test for several competing reconstructions of sea level during Marine Isotope Stage (MIS) 7 (refs 2, 3, 6-8) (Fig. 1).

A common approach to reconstruct past sea level is to measure the age and elevation of geological archives that formed at a known position relative to the sea surface, such as corals ${ }^{7}$ that grow in shallow water, or speleothems $s^{9,10}$ that grow in caves and serve as an upper limit to sea-level elevation. The strength of this method lies in the degree of confidence afforded by an accurate and precise chronology, such as provided by the U-Th dating technique, and in the ability to precisely measure the elevation relative to present sea level. We have applied this technique to submerged speleothems recovered from Argentarola Cave, Italy, that preserve alternating

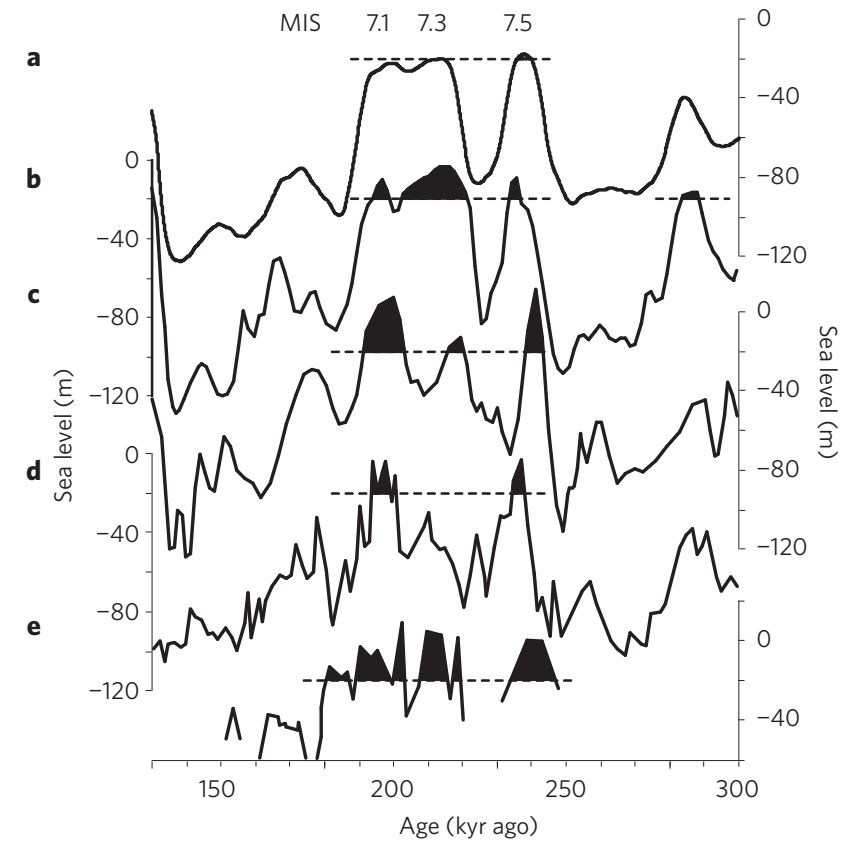

Figure 1 | Sea-level curves derived using five different methods.

a, Model ${ }^{6}$ driven by benthic oxygen isotope $\left(\delta^{18} \mathrm{O}\right)$ stack. $\mathbf{b}$, Sea-level curve based on benthic $\delta^{18} \mathrm{O}$ data and ice-volume model ${ }^{8}$. $\mathbf{c}$, Reconstructions on the basis of sea water $\delta^{18} \mathrm{O}$ calculated from paired $\mathrm{Mg} / \mathrm{Ca}$ and $\delta^{18} \mathrm{O}$ measurements on planktonic foraminifera ${ }^{2}$. d, Reconstruction of Red Sea sea water $\delta^{18} \mathrm{O}$ (ref. 3). e, Reconstruction derived from open-system U-Th ages of corals ${ }^{7}$. Shading indicates periods of time for which sea level rises above $-20 \mathrm{~m}$ (dashed lines), the approximate depth of Argentarola Cave speleothems. Note differences in the number of MIS 7 highstands predicted to exceed $-20 \mathrm{~m}$ and the difference in elevation predicted for MIS 7.3 in particular.

layers of spelean calcite that grew when the caves were above sea level and biogenic calcite secreted by serpulid worms that colonized the speleothems during sea water submergence ${ }^{4}$. One of the advantages of the speleothem archive relative to corals is that dense spelean calcite is less susceptible to alteration, which allows for reconstructions further back in time. Furthermore, by dating the timing of speleothem growth, the entire duration of time for a given sea-level highstand can be bracketed. In contrast, it is much more challenging to unambiguously determine the entire duration of

${ }^{1}$ Research School of Earth Sciences, The Australian National University, 1 Mills Rd, Canberra, ACT 0200, Australia, ${ }^{2}$ CEREGE, UMR 6635 CNRS,

Aix-Marseille University, IRD, College de France, Europole de I'Arbois BP 80, F-13545 Aix-en-Provence Cdx 4, France, ${ }^{3}$ ENEA, cre Casaccia, via Anguillarese 301, 00123 Rome, Italy. 'Present address: Australian Nuclear Science Technology Organisation, Institute for Environmental Research, Menai, NSW 2234, Australia. *e-mail: andrea.dutton@anu.edu.au. 
Table 1 | Timing of sea-level highstands at Argentarola Cave.

\begin{tabular}{lllll} 
MIS & \multicolumn{3}{c}{ Sea-level highstand } & \multicolumn{2}{c}{$\begin{array}{l}\text { Summer insolation } \\
\text { peak at } 65^{\circ} \mathbf{N}^{\dagger}\end{array}$} \\
\cline { 2 - 5 } & Start (kyr ago) & End (kyr ago) & Duration (kyr) & 197 \\
7.1 & $201.5 \pm 1.7$ & $189.7 \pm 1.5$ & $\sim 12$ & 218 \\
7.3 & $217.2 \pm 1.9$ & $206.0 \pm 1.9$ & $\sim 11$ & 241 \\
\hline
\end{tabular}

*Timing determined by U-Th dates in this study and ref. 5 includes $2 \sigma$ errors on ages. From youngest to oldest, these six ages are from speleothems ASI, ASI, ASI, ASE, ASE and ASN.

Summer = JJA; ref. 30

coral reef growth during a highstand. This work builds on a previous study that established the timing of MIS 7.1 at Argentarola Cave ${ }^{5}$ by extending the record back further in time and examining specimens across a range of depths.

We generated $36 \mathrm{U}-\mathrm{Th}$ ages to determine the timing of speleothem growth in two stalagmites from Argentarola (ASN and ASE) that were collected from -18 and $-21 \mathrm{~m}$, respectively, relative to present sea level (see Supplementary Table S1, Figs S1-S3). Ages of spelean calcite bracketing the marine-derived biogenic layers permit us to assign a chronology to highstands recorded in these speleothems and to define periods of continuous speleothem growth when sea level was below the elevation of the cave (Table 1, Fig. 2). Speleothems in Argentarola Cave suggest that sea level rose above $-18 \mathrm{~m}$ after $248.9 \pm 1.9$ thousand years ago (kyr) and dropped below $-21 \mathrm{~m}$ before $231.0 \pm 3.0 \mathrm{kyr}$, subsequently rose above $-21 \mathrm{~m}$ after $217.2 \pm 1.9 \mathrm{kyr}$ and dropped below $-18.5 \mathrm{~m}$ before $206.0 \pm 1.9 \mathrm{kyr}$ and finally rose above $-18.5 \mathrm{~m}$ after $201.5 \pm 1.7 \mathrm{kyr}$ and dropped below $-18.5 \mathrm{~m}$ before $189.7 \pm 1.5 \mathrm{kyr}$. The timing of interglacial highstands at Argentarola Cave is indicative of eustatic sea-level variations because the time difference between local sea-level reaching $-18 \mathrm{~m}$ at Argentarola and the calculated timing of $-18 \mathrm{~m}$ eustatic sea level (ice-equivalent volume) is very small (estimated at $<0.1 \mathrm{kyr}$ ) relative to the precision of the U-Th ages (1.5-3.0 kyr) (see Supplementary Fig. S9). Although differences in growth rate, sample dimension and placement, and potential hiatuses during the subaerial to marine transition, affect our estimate of the timing of the highstand, the analytical precision of the U-Th dates is sufficient to capture small offsets that may be introduced by these factors (see Supplementary Information). These U-series data provide a maximum estimate for the duration of the highstand above $-18 \mathrm{~m}$, as our ages represent the timing of stalagmite growth before and after submergence by sea water.

In addition to constraining the timing of these highstands, our dataset also reveals the elevation of sea level during two substages: MIS 7.2 and 7.3. During MIS 7.2 sea level fell below $-18.5 \mathrm{~m}$ but remained above $-21 \mathrm{~m}$, where continuous serpulid calcite deposition is observed from the beginning of MIS 7.3 until the end of MIS 7.1. Furthermore, we conclude that the MIS 7.3 highstand peaked near $-18 \mathrm{~m}$ on the basis of (1) the presence of an MIS 7.3 serpulid layer at -18.5 and $-21 \mathrm{~m}$ (in ASI and ASE) and its absence in the specimen from $-18 \mathrm{~m}$ (ASN) and (2) evidence of dissolution just below the MIS 7.2 layer in ASN. Such dissolution can occur where sea water meets the overlying freshwater lens, because calcite saturation becomes depressed at intermediate salinities. Dissolution is also observed in another undated specimen, stalagmite $\mathrm{O}(-18 \mathrm{~m})$. Yet, ASE $(-21 \mathrm{~m})$ does not show similar evidence of dissolution, indicating that corrosive conditions were limited to a higher elevation in the cave. This combination of observations leads us to deduce that near $-18 \mathrm{~m}$ the cave was subjected to dissolution in the halocline during the MIS 7.3 highstand (see Supplementary Information for further detail of sample descriptions).

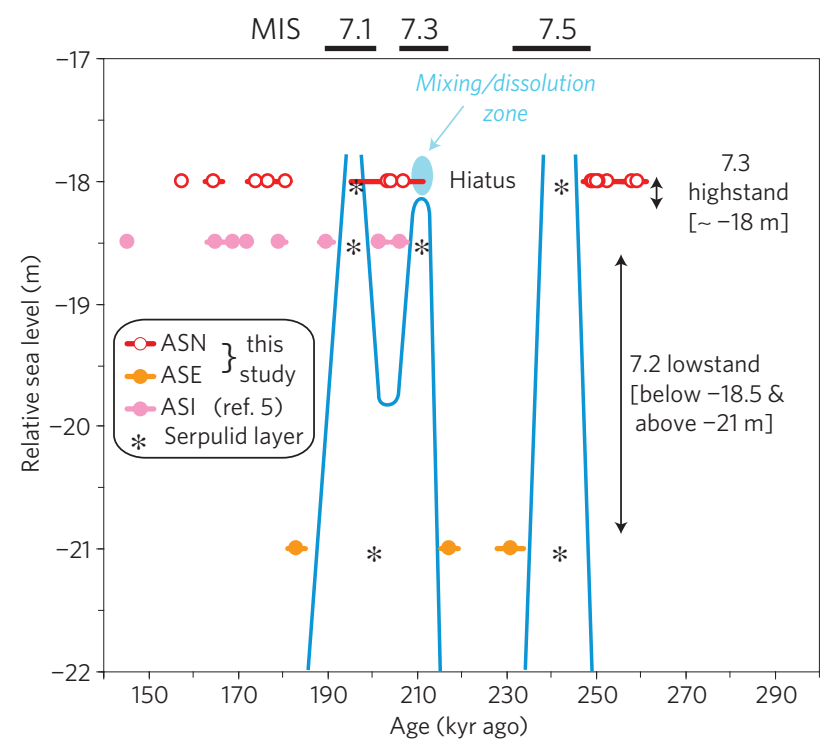

Figure 2 | Timing and position of sea-level highstands in Argentarola Cave during MIS 7. $U$-Th ages (circles with $2 \sigma$ error bars) for three specimens indicate periods of speleothem growth when the cave was subaerially exposed. The sea-level curve must be below these data points, but above any marine-derived serpulid layers (asterisks). Peak elevations of the MIS 7.5 and 7.1 highstands occur above $-18 \mathrm{~m}$. We do not observe evidence in these specimens for suborbital sea-level oscillations posited to occur during glacial termination III (TIII) and after MIS 7.1 (refs 18, 21).

One of the major outcomes of this investigation is evidence that the MIS 7.3 highstand peaked near $-18 \mathrm{~m}$ and was lower than the MIS 7.5 or 7.1 highstands. Heretofore, there has been considerable ambiguity regarding the relative heights of these three highstands (Fig. 1). Sea levels estimated from reconstructions based in whole or part on benthic oxygen isotope $\left(\delta^{18} \mathrm{O}\right)$ data ${ }^{1,6,8}$ predict similar peak elevations near to (or below) present sea level, whereas some sea-level curves based on other proxies indicate a lower elevation for MIS 7.3 (refs 2, 3). In addition to Argentarola Cave, there is evidence from the Bahamas ${ }^{9-11}$, Barbados ${ }^{12}$, South Australia ${ }^{13}$ and New Zealand ${ }^{14}$ for only two prominent highstands (7.5 and 7.1) during the penultimate interglacial (Fig. 3). Significantly, our reconstruction of relative elevations of the three highstands during MIS 7 agrees with sea-level curves based on sea water $\delta^{18} \mathrm{O}$ calculations derived using two very different techniques ${ }^{2,3}$ and not with those based on benthic foraminiferal $\delta^{18} \mathrm{O}$ ( $\left.\mathrm{refs} 1,6,8\right)$. We postulate that this discrepancy arises out of a significantly higher contribution of temperature to the benthic signal during MIS 7.3, when Northern Hemisphere summer insolation was particularly high and was closely followed by an unusually high Southern Hemisphere summer insolation maximum (Fig. 4).

For comparison, we show the elevation and U-Th ages of corals from Barbados and of a submerged flowstone from the Bahamas 


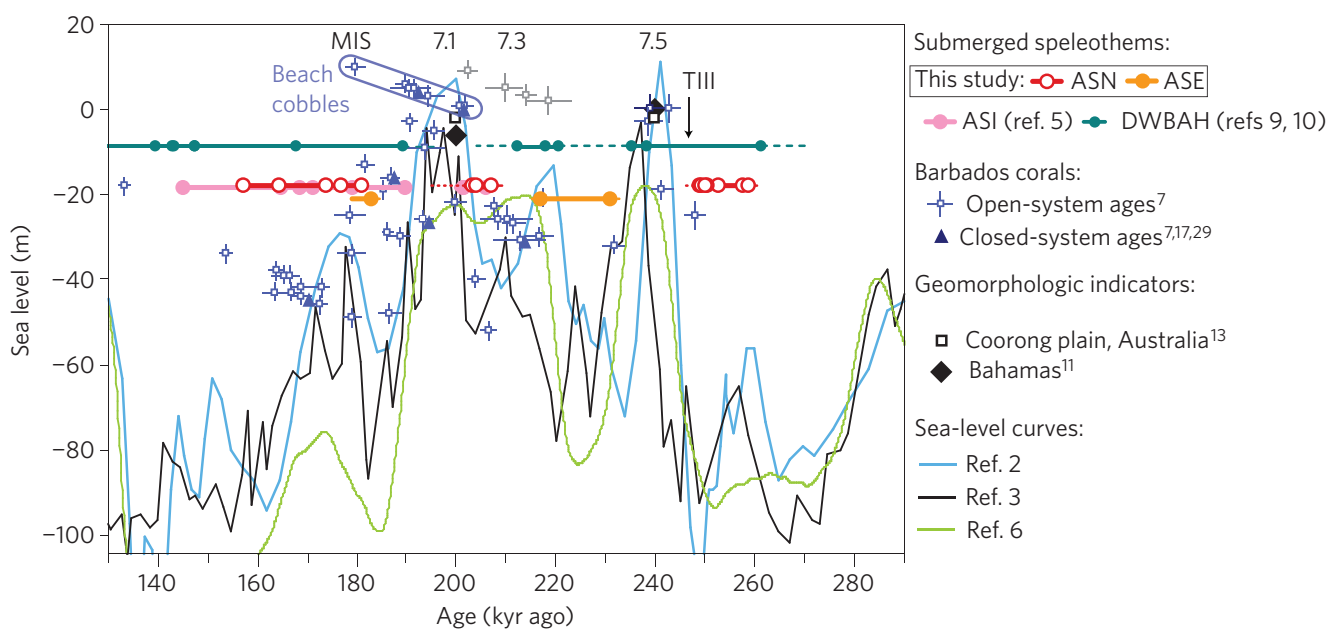

Figure 3 | Summary of MIS 7 highstands. Submerged speleothem U-Th data represent growth periods and should be above the sea-level curve, whereas coral data should be just below the curve. Solid lines connecting speleothem U-Th ages represent periods of uninterrupted growth. The error bars for samples next to hiatuses are shown as dashed lines. Peak MIS 7.5 coral data were assumed to sit at modern sea-level ${ }^{7}$. The remainder of the Barbados coral elevations are calculated assuming constant uplift rates, which introduces some error into the elevation estimates ${ }^{7}$. Closed-system ages are shown for corals with $\delta^{234} U_{\text {inital }}$ within $2 \%$ of sea water ${ }^{7,17,29}$.

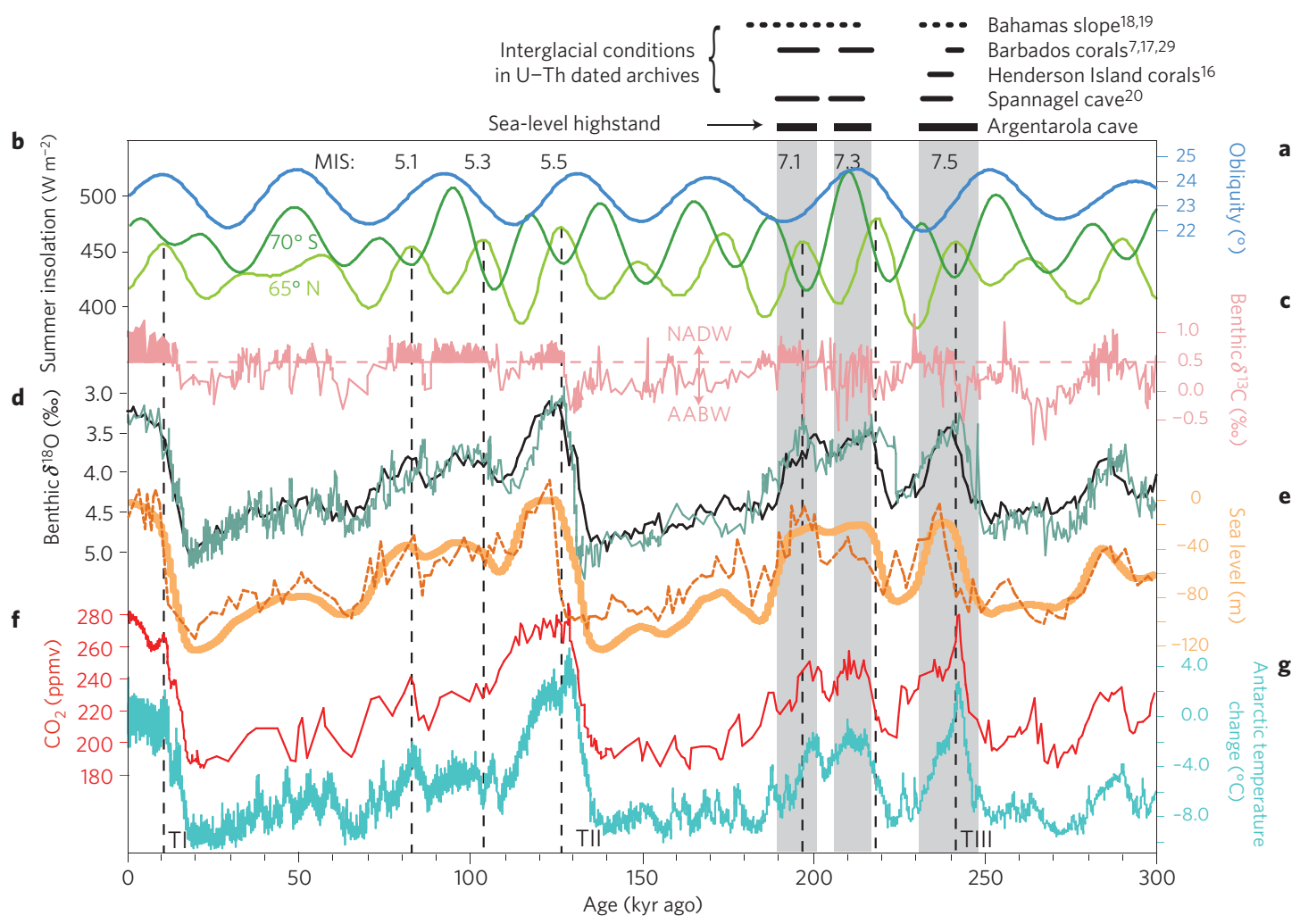

Figure 4 | Sea-level and climate reconstructions from MIS 7 to present. MIS 7 highstands at Argentarola (Table 1) denoted by vertical grey bars. a,b, Obliquity (a) and summer insolation (b) curves at $65^{\circ} \mathrm{N}$ (JJA) (maxima shown by dotted lines in MIS 7 and MIS 5) and 70 $\mathrm{S}$ (DJF) (ref. 30). c, Iberian Margin benthic carbon isotope $\left(\delta^{13} \mathrm{C}\right)$ data ${ }^{26}$ highlight the unusual nature of MIS 7.3. d, Benthic $\delta^{18} \mathrm{O}$ stack (black) and benthic $\delta^{18} \mathrm{O}$ from the Iberian Margin $^{26}$ (blue). e, Sea-level reconstructions ${ }^{3,6}$ (dashed and solid orange lines, respectively). f, Compiled Antarctic ice-core $\mathrm{CO}_{2}$ (ref. 24). $\mathbf{g}$, EPICA Dome C temperature ${ }^{23}$. Terminations labelled as TI-TIII.

(DWBAH) (Fig. 3). U-Th dates for DWBAH have been corrected using a more appropriate ${ }^{230} \mathrm{Th} /{ }^{232} \mathrm{Th}$ ratio for this site $\mathrm{e}^{15}$, which shifts the ages younger relative to those originally reported ${ }^{9,10}$. Regardless of whether this correction is applied or not, the primary-and crucial—observation from this specimen is that sea level overtook the elevation of this flowstone during only two of the three MIS 7 highstands. Most of the Barbados corals sampled from
MIS 7 reef terraces have experienced diagenesis, so the U-Th ages of these corals have been estimated using a model of open-system diagenesis ${ }^{7}$. The majority of these data are in excellent agreement with the Argentarola data, with the exception of four corals from a single outcrop with unusually high $\delta^{234} U_{\text {initial }}$ values $(>330 \%$, representing the four most altered samples in the entire dataset ${ }^{7}$, shown in grey in Fig. 3). We conclude that the open-system model $^{7}$ 
is unable to accurately compensate for such extreme alteration and that these data are unreliable. With this exclusion, the remaining Barbados coral data cluster near $-20 \mathrm{~m}$ during MIS 7.3, consistent with our $-18 \mathrm{~m}$ estimate from Argentarola.

The duration of interglacial conditions recorded in several absolutely dated archives ${ }^{7,16-20}$ (horizontal black lines, Fig. 4) is in good agreement with the timing of sea-level highstands at Argentarola (vertical grey bars, Fig. 4), particularly bearing in mind the potentially patchy nature of coral data in recording the entire duration of a highstand. U-Th ages of interglacial conditions in Spannagel Cave (Austrian Alps) ${ }^{20}$ agree within error with our U-Th ages, with the exception of the onset of MIS 7.5 (glacial termination III (TIII)). The lag in establishment of interglacial conditions at Spannagel Cave relative to timing of sea-level change that is reflected in our data from Argentarola may be related to delayed retraction of the polar front in the North Atlantic ${ }^{21}$.

More continuous records of climate and sea-level change during the penultimate interglacial are available from ice cores, deepsea cores and models, but these reconstructions generally rely on age models that are tuned to orbital parameters based on different assumptions about forcing and response. Hence they cannot be used to determine the phasing of various elements of the climate system unless they can first be calibrated against absolutely dated records of the response. Of the reconstructions discussed here, the EDC3 timescale ${ }^{22}$ of the Antarctic ice-core data ${ }^{23,24}$ (Fig. 4f, g) is considered more robust (that is, more independent than a tuning regime that prescribes phase lags relative to orbital parameters as in ref. 1).

Temperature rise is generally thought to precede ice volume reduction during the transition into a highstand with a time lead of $\sim 3 \mathrm{kyr}$ or greater ${ }^{2}$, but these two variables may have operated in phase for the major termination events in the past 500,000 years (ref. 25). Even allowing an additional 2-3 kyr for sea level to reach its peak during MIS 7.5 and 7.1, data from Argentarola and Barbados, ${ }^{7,17}$ indicate highstands that either precede or are simultaneous (within error) with temperature peaks in Antarctica ${ }^{23}$ and interglacial conditions in the $\mathrm{Alps}^{20}$ (Fig. 4). Because the precision of U-Th ages from Argentarola approaches the potential magnitude of the phase $\mathrm{lag}^{2}$, the MIS 7.5 highstand is the only one that significantly predates the temperature peak in Antarctic ice cores. It is tempting to ascribe the observed timing of TIII at Argentarola Cave to early cessation of speleothem growth due to decreased precipitation during peak glacial conditions; however, we acknowledge that extreme regional aridity is not entirely supported by speleothem growth rates, which reach their respective maxima leading into MIS 7.5 both in the Austrian Alps ${ }^{20}$ and at Argentarola.

The MIS 7.5 and 7.1 highstands in Argentarola Cave predate Northern Hemisphere summer insolation maxima by as much as 2,000-5,000 years whereas the MIS 7.3 highstand reaches its apex within $\sim 1,000$ years of the insolation maximum (Table 1 , Fig. 4). Peak $\mathrm{CO}_{2}$ concentrations and Antarctic temperatures also suggest more of a lag relative to the insolation peak during MIS 7.3 (refs 23, 24), which follows the extremely cold conditions of MIS 7.4 observed in pollen, temperature and benthic $\delta^{18} \mathrm{O}$ records $\mathrm{s}^{1,21,23,26}$. The MIS 7.4-7.3 transition has even been likened to a termination event because of the magnitude of change in the benthic $\delta^{18} \mathrm{O}$ signal $^{27}$. The delayed timing and dampened amplitude observed for the MIS 7.3 highstand at Argentarola may have been caused by MIS 7.4 glaciation, which was extensive, but according to ref. 27 was not enough to cause coalescence of the Cordilleran and Laurentide ice sheets, which has been postulated as a key factor in triggering the rapid retreat of ice ${ }^{25}$. For the other two highstands, MIS 7.5 and 7.1, our data cannot constrain the time at which sea level reached its final peak, but, even allowing an additional 2-3 kyr for this to occur, our data do not support a significant lag of sea level relative to insolation as assumed in the construction of most deep-sea core chronologies.

\section{Methods}

Samples from ASN were prepared and analysed using established analytical protocols for U-Th dating ${ }^{28}$ using a Finnigan Neptune multicollector-inductively coupled plasma-mass spectrometer at ANU. Three additional samples from speleothem ASE were measured at CEREGE using a TIMS VG54-30 mass spectrometer ${ }^{5}$. The compatibility between ages measured at ANU and CEREGE was ascertained by analysis of two coral samples (Cladocora caespitosa from Versilia Plain, Italy). U-Th ages measured on the same corals in both laboratories agree within analytical errors for these samples, which grew during MIS 7 and MIS 6.5.

${ }^{238} \mathrm{U}$ concentrations of the speleothem calcite are fairly high $(\sim 0.3$ to $1.5 \mathrm{ppm})$ and the detrital thorium content $\left({ }^{232} \mathrm{Th}\right)$ is generally low, except for some of the samples taken immediately adjacent to serpulid calcite layers. Serpulid calcite layers are comparatively high in both ${ }^{238} \mathrm{U}$ and ${ }^{232} \mathrm{Th}$, owing to the high amount of sediment entrained in these layers, and hence were not analysed. One age inversion appears during the MIS 8 growth of ASN2 along a layer of fluid inclusions, which may have contributed some contamination to this sample (TT16, see Supplementary Table S1). Two samples taken at the contact between spelean and serpulid calcite that show visible evidence of small-scale dissolution also yield anomalously young ages (TT02 and TT08). These three samples were excluded from further analysis. Samples taken from the altered portion of ASN1 confirm that diagenesis has affected the U-Th isotopes in this area. Owing to small-scale dissolution features present in ASN, we made thin sections for detailed petrographic analysis of all areas sampled and thick sections to characterize the elemental composition of speleothem calcite and biogenic calcite layers using laser-ablation inductively-coupled-plasma mass spectrometry. A suite of elements was measured (U, Ca, Mg, Sr, Th, Ba, Mn, $\mathrm{Y}, \mathrm{La}, \mathrm{Ce}, \mathrm{Pr}, \mathrm{Nd}$ and $\mathrm{Er}$ ) to establish the elemental signatures of the biogenic calcite relative to speleothem calcite, and to provide a working guideline of uranium concentrations that were used to estimate the sample size required for U-series analysis (see Supplementary Fig. S5). These elemental profiles served as additional checks for remnants of serpulid layers where part or all of the biogenic layer has been removed. The elemental data confirmed our visual and petrographic analysis but did not identify any additional remnant serpulid layers.

Received 24 September 2008; accepted 23 February 2009; published online 6 April 2009

\section{References}

1. Lisiecki, L. E. \& Raymo, M. E. A Pliocene-Pleistocene stack of 57 globally distributed benthic $\delta^{18} \mathrm{O}$ records. Paleoceanography 20, PA1003 (2005).

2. Lea, D. W., Martin, P. A., Pak, D. K. \& Spero, H. J. Reconstructing a $350 \mathrm{kyr}$ history of sea level using planktonic $\mathrm{Mg} / \mathrm{Ca}$ and oxygen isotope records from a Cocos Ridge core. Quat. Sci. Rev. 21, 283-293 (2002).

3. Siddall, M. et al. Sea-level fluctuations during the last glacial cycle. Nature 423, 853-858 (2003).

4. Antonioli, F. et al. 215-ka history of sea-level oscillations from marine and continental layers in Argentarola cave speleothems (Italy). Glob. Planet. Change 43, 57-78 (2004).

5. Bard, E., Antonioli, F. \& Silenzi, S. Sea-level during the penultimate interglacial period based on a submerged stalagmite from Argentarola Cave (Italy). Earth Planet. Sci. Lett. 196, 135-146 (2002).

6. Bintanja, R., van de Wal, R. S. W. \& Oerlemans, J. Modelled atmospheric temperatures and global sea levels over the past million years. Nature 437, 125-128 (2005).

7. Thompson, W. G. \& Goldstein, S. L. Open-system coral ages reveal persistent suborbital sea-level cycles. Science 308, 401-404 (2005).

8. Waelbroeck, C. et al. Sea-level and deep water temperature changes derived from benthic foraminifera isotopic records. Quat. Sci. Rev. 21, 295-305 (2002).

9. Li, W.-X. et al. High-precision mass-spectrometric uranium-series dating of cave deposits and implications for palaeoclimate studies. Nature 339, 534-536 (1989).

10. Lundberg, J. \& Ford, D. C. Late Pleistocene sea level change in the Bahamas from mass spectrometric U-series dating of submerged speleothem. Quat. Sci. Rev. 13, 1-14 (1994).

11. Hearty, P. J. \& Kindler, P. Sea-level highstand chronology from stable carbonate platforms (Bermuda and the Bahamas). J. Coast. Res. 11, 675-689 (1995).

12. Schellmann, G. \& Radtke, U. The Marine Quaternary of Barbados (Geographisches Institut der Universitat zu Koln, 2004).

13. Murray-Wallace, C. V. Pleistocene coastal stratigraphy, sea-level highstands and meotectonism of the southern Australian passive continental margin-a review. J. Quat. Sci. 17, 469-489 (2002).

14. Pillans, B. Climate and sea level during oxygen isotope stage 7b: On-land evidence from New Zealand. Quat. Res. 29, 176-185 (1988).

15. Richards, D. A. \& Dorale, J. A. in Uranium-Series Geochemistry Vol. 52 (eds Bourdon, B., Henderson, G. M., Lundstrom, C. C. \& Turner, S. P.) 407-460 (Mineralogical Society of America, 2003). 
16. Andersen, M. The Precise Measurement of Uranium-Series Isotopes in the Marine Environment. PhD Thesis, ETH (2006).

17. Gallup, C. D., Edwards, R. L. \& Johnson, R. G. The timing of high sea levels over the past 200,000 years. Science 263, 796-800 (1994).

18. Henderson, G. M., Robinson, L. F., Cox, K. \& Thomas, A. L. Recognition of non-Milankovitch sea-level highstands at 185 and 343 thousand years ago from U-Th dating of Bahamas sediment. Quat. Sci. Rev. 25, 3346-3358 (2006).

19. Robinson, L., Henderson, G. M. \& Slowey, N. C. U-Th dating of marine isotope stage 7 in Bahamas slope sediments. Earth Planet. Sci. Lett. 196, 175-187 (2002).

20. Spötl, C., Scholz, D. \& Mangini, A. A terrestrial U/Th-dated stable isotope record of the Penultimate Interglacial. Earth Planet. Sci. Lett. 276, 283-292 (2008).

21. Roucoux, K. H., Tzedakis, P., De Abreu, L. \& Shackleton, N. J. Climate and vegetation changes 180,000-345,000 years ago recorded in a deep-sea core off Portugal. Earth Planet. Sci. Lett. 249, 307-325 (2006).

22. Parrenin, F. et al. The EDC3 chronology for the EPICA Dome C ice core. Clim. Past 3, 485-497 (2007).

23. Jouzel, J. et al. Orbital and millennial Antarctic climate variability over the past 800,000 years. Science 317, 793-797 (2007).

24. Lüthi, D. et al. High-resolution carbon dioxide concentration record 650,000-800,000 years before present. Nature 453, 379-382 (2008).

25. Bintanja, R. \& van de Wal, R. S. W. North American ice-sheet dynamics and the onset of 100,000-year glacial cycles. Nature 454, 869-872 (2008).
26. Martrat, B. et al. Four climate cycles of recurring deep and surface water destabilizations on the Iberian Margin. Science 317, 502-507 (2007).

27. Huybers, P. \& Wunsch, C. Obliquity pacing of the late Pleistocene glacial terminations. Nature 434, 491-494 (2005).

28. McCulloch, M. T. \& Mortimer, G. Applications of the ${ }^{238} \mathrm{U}-{ }^{230}$ Th decay series to dating of fossil and modern corals using MC-ICPMS. Aust. J. Earth Sci. 55, 955-965 (2008).

29. Edwards, R. L., Cheng, H., Murrell, M. T. \& Goldstein, S. L. Protactinium-231 Dating of Carbonates by Thermal Ionization Mass Spectrometry: Implications for Quaternary Climate Change Vol. 276, 782-786 (1997).

30. Laskar, J. The chaotic behaviour of the solar system: A numerical estimate of the size of the chaotic zones. Icarus 88, 266-291 (1990).

\section{Acknowledgements}

We thank J. Desmarchelier, G. Mortimer and L. Kinsley for analytical assistance and G. Caramanna for sampling stalagmite ASN in the cave. This work was supported by a grant from the Australian Research Council and the VECTOR project funded by the Italian Ministry of Education, University and Research.

\section{Additional information}

Supplementary information accompanies this paper on www.nature.com/naturegeoscience. Reprints and permissions information is available online at http://npg.nature.com/ reprintsandpermissions. Correspondence and requests for materials should be addressed to A.D. 